\title{
TINJAUAN SISTEMATIS TENTANG TEKNIK DELPHI DAN KAITANNYA TERHADAP ISU KEFARMASIAN TERKINI
}

\author{
Anshar Saud \\ Laboratorium Farmasi Klinik, Fakultas Farmasi, Universitas Hasanuddin, Makassar
}

Kata Kunci :

Delphi Technique, Pharmacy, Pharmaceutical, Pharmaceutical Care, Pharmacist

Masuk 14-01-2019

Revisi 25-04-2019

Diterima 30-04-2019

Korespondensi

\section{Anshar Saud}

Ansharsaud@unhas.ac.id

Copyright

(C) 2019 Majalah Farmasi Farmakologi Fakultas

Farmasi · Makassar

Diterbitkan tanggal 30-04-2019

Dapat Diakses Daring Pada:

http://journal.unhas.ac.id /index.php/mff

\begin{abstract}
ABSTRAK
Delphi technique has been knowned in variety research of studies and countries for almost eight decades as one of reliable decision making method. Its success and relation in pharmacy field has been examined but not yet catalogue recently in a comprehensive manner. The objective of this study was to review existing literature studies on the topic of Delphi technique and its relation on current pharmaceutical issues to provide an analysis of its success and impact in pharmacy and health sector. A search of 6 electronic databases i.e: Google Scholar, MEDLINE, PubMed, ScienceDirect, Web of Science and Proquest was conducted during November 2018. A scientific review of literature (2008-2018) was performed to identify and collate information from relevant, peer reviewed original study articles investigating Delphi technique employed in pharmaceutical issues. A thematic analysis was undertaken to categorize categories of pharmacy, pharmaceutical, pharmaceutical care and pharmacist. Thirty two original study articles were included in this review. All articles were based in the U.S., Europe, Australia and Asia. After reviewing all the articles, 5 themes with 13 categories were generated. These themes included essential role of pharmacist in healthcare, pharmacy professionalism, medication management protocol, pharmacy education, and drug policy. It concluded that overall, through this review it is evident that there are a number of themes on pharmacy issues that employed by Delphi techniques. This review indicated that although Delphi technique are successful and to be satisfactory applied in pharmacy field, the usage of technique in pharmacy issues need to be further enhanced.
\end{abstract}

\section{PENDAHULUAN}

Farmasis telah memperluas peran dan tanggung jawabnya sebagai hasil dari reformasi pelayanan kesehatan primer (1). Pada saat yang bersamaan, metode konsensus seperti teknik survei Delphi telah digunakan untuk membantu meningkatkan pengambilan keputusan yang efektif dalam bidang kesehatan dan sosial. Survei Delphi adalah teknik fasilitasi grup dimana proses multitahap yang berulang didesain untuk mengubah opini menjadi konsensus kelompok (2). Walaupun belum begitu banyak digunakan, metode ini memiliki potensi sebagai alat bantu penelitian dalam riset pelayanan kesehatan (health services research) (3). Teknik Delphi menggunakan interaksi antar anggota grup (disebut dengan panel) melalui kuesioner bukan komunikasi tatap muka. Hal ini berarti akan melindungi anonimitas pasrtisipan jika hal itu relevan. Teknik ini dikembangkan oleh RAND Corporation pada tahun 1953, awalnya untuk riset pertahanan militer (4).

Evolusi dalam pelayanan kesehatan dan praktik kefarmasian menunjukkan banyaknya kesempatan baru farmasis untuk menunjukkan fungsinya dan memberikan pelayanan yang tidak seperti peran-peran tradisionalnya. Profesi farmasi bekerja untuk mencapai model yang meluas dan standar perawatan yang semata-mata ditentukan oleh kebutuhan pasien dan populasi (5). Merespon hal ini kurikulum sekolah farmasi berevolusi mempertahankan kompetensi profesionalnya dengan mengidentifikasi dan menganalisa masalah-masalah farmasi kontemporer; dan berpartisipasi dalam pembelajaran mandiri dan pengembangan profesional.(6) Isuisu kefarmasian kontemporer tersebut meliputi beberapa tema (dan subtema) yang luas meliputi penyediaan layanan kesehatan, praktik kefarmasian, farmasis dalam peran perawatan pasien, praktik kefarmasian dalam setting nontradisional serta isu farmasis di pendidikan tinggi, manajemen organisasi kesehatan, regulasi dan industry (5).

Dengan adanya evolusi dalam pelayanan kesehatan dan praktik kefarmasian ini akan diikuti oleh meluasnya orientasi penelitian dalam bidang kefarmasian khususnya riset praktik farmasi (pharmacy practice research). Sejumlah teori dan metode yang berguna dalam riset praktik farmasi berasal dari bidang ilmu sosiologi, psikologi, antropologi, pedagogi dan ekonomi kesehatan (7). Tujuan studi ini adalah meninjau literaturliteratur penelitian farmasi untuk melihat tematema dan sub-sub tema yang terbentuk dengan menggunakan salah satu metode teknik mengambilan keputusan yaitu teknik Delphi. Tujuan khusus dari tinjauan ini adalah secara kritis dan komprehensif menilai sejauh mana penggunaan teknik ini dalam penelitian berbasis farmasi, sehingga dengan penilaian ini diharapkan diperoleh pemahaman tentang perubahan apa yang dapat dipertimbangkan untuk pengembangan profesional farmasis dan pendidikan farmasi yang lebih baik.

\section{METODE PENELITIAN}

\section{Strategi Pencarian}

Review ini mengikuti pedoman PRISMA dalam melakukan tinjauan sistematik. Pencarian literatur dilakukan antara 1 November 2018 hingga 30 November 2018 untuk mengidentifikasi 
artikel karya asli yang ditinjau oleh sejawat (original study peer reviewed) yang telah terpublikasi dan ditulis dalam bahasa Inggris. Pangkalan data (database) yang digunakan yaitu: Google Scholar (2008-sekarang), MEDLINE (2008sekarang), PubMed (2008-sekarang), ScienceDirect (2008sekarang), Web of Science (2008-sekarang) dan Proquest (2008-sekarang). Telah digunakan, dikembangkan dan diimplementasikan pula strategi pencarian dengan kata kunci sebagai berikut: ("Delphi" OR "Delphi Technique" OR "Delphi Method") AND ("pharmacy*" OR "pharmacy practice" OR "pharmaceutical care" OR "pharmacist*") AND ("US" OR "United States" OR "America* OR "England" OR "United Kingdom" OR "Europe" OR "Netherlands" OR "Asia" OR "Africa*" OR "Australia" OR "New Zealand"). Kata kunci dikombinasikan dan diintegrasikan dalam pencarian pangkalan data. Hasil pencarian ('hits') oleh pangkalan data secara mendetail terlampir dalam lampiran. Pencarian termasuk dalam aturan "Operator Boolean" dimana istilah yang dicari menggunakan "AND" untuk mengkombinasikan kata kunci dan "OR" untuk menghilangkan adanya duplikasi. Penilaian referensi dari artikel yang ditarik juga dilakukan untuk memperoleh artikel tambahan yang relevan yang mungkin terlewatkan pada pencarian awal.

Seleksi artikel dan koleksi data

Dari semua pencarian pangkalan data, sebanyak 165 artikel berhasil ditarik. Judul dan abstrak dari artikel yang ditarik ini kemudian ditinjau untuk menunjukkan relevansinya terhadap topik farmasi. Proses ini menyeleksi artikel hingga diperoleh 88 artikel yang potensial untuk ditinjau. Pemilihan artikel yang kesemuanya merupakan artikel lengkap dalam bahasa Inggris ini kemudian diseleksi lagi untuk menghindari adanya duplikasi. Dibuat tabel dengan format yang memuat judul artikel, pengarang, tujuan penelitian dan hasil penelitian. Artikel penelitian yang nampak meragukan memiliki artikel yang lengkap ditinjau kembali relevansinya untuk dimasukkan dalam studi. Artikel tersebut akan dieksklusi jika tidak relevan atau ditambahkan ke dalam tabel jika relevan untuk ditinjau lebih lanjut. Tabel awal terdiri atas artikel karya asli, riwayat artikel, editorial, tinjauan, komentar dan opini. Sebanyak 52 dianggap relevan memenuhi syarat. Pada proses selanjutnya, setelah dieksklusi berdasarkan kriteria eksklusi diperoleh 32 artikel yang diputuskan untuk dimasukkan ke dalam studi. Artikel inilah yang dibaca dengan lengkap untuk diteliti lebih lanjut. Lihat gambar 1 untuk deskripsi lengkap dari proses studi

\section{Analisis}

Analisis tema dari studi artikel dilakukan dengan berdasarkan topik utama dari tinjauan (teknik Delphi) dan tema serta subtema yang diidentifikasi dan ditambahkan ke dalam tinjauan saat keduanya muncul, hingga tidak terdapat lagi tema yang dapat teridentifikasi dan analisis tema dianggap selesai. Dengan menggunakan berbagai kategori dan klasifikasi yang menggunakan teknik Delphi dari analisis ini, maka dapat diidentifikasi dan didiskusikan lebih lanjut.

Tinjauan ini mengidentifikasi teknik Delphi sebagai prosedur atau alat yang digunakan untuk memecahkan masalah yang berkaitan dengan isu kefarmasian (dapat dilihat di tabel 1).

\section{HASIL DAN PEMBAHASAN}

Terdapat 32 artikel karya asli yang dimasukkan ke dalam studi ini; semuanya berasal dari negara-negara di 4 benua yaitu: Amerika (15), Eropa (11) , Australia (5) dan Asia (1). Setelah meninjau semua artikel, diperoleh 5 tema dengan 13 subkategori. Tema-tema ini adalah peran esensial farmasis pada pelayanan kesehatan, profesionalisme kefarmasian, protokol manajemen pengobatan, pendidikan farmasi, dan kebijakan obat. Artikel-artikel tersebut dirangkum dalam tabel 2 dan tema-tema yang dihasilkan dirangkum dalam tabel 3.

\begin{tabular}{|c|c|c|}
\hline No & Kategori & Kriteria Inklusi \\
\hline 1 & Tahun rilis & $2008-2018$ \\
\hline 2 & Tipe publikasi & $\begin{array}{l}\text { Teks lengkap, artikel peer reviewed } \\
\text { dalam bahasa Inggris }\end{array}$ \\
\hline 3 & $\begin{array}{l}\text { Topik yang } \\
\text { diikutkan }\end{array}$ & $\begin{array}{l}\text { Delphi, Delphi Technique, Delphi } \\
\text { Method, pharmacy practice, } \\
\text { pharmaceutical care, pharmacist }\end{array}$ \\
\hline 4 & $\begin{array}{l}\text { Metodologi riset } \\
\text { penelitian }\end{array}$ & $\begin{array}{l}\text { Harus meneliti beberapa aspek } \\
\text { farmasi, praktik kefarmasian dan } \\
\text { pharmaceutical care dengan } \\
\text { menggunakan teknik atau metode } \\
\text { Delphi }\end{array}$ \\
\hline \multirow[t]{2}{*}{5} & Bias & $\begin{array}{l}\text { Harus tidak terdapat bias dalam } \\
\text { penelitian - termasuk dalam } \\
\text { metode, desain studi, koleksi data, } \\
\text { analisis data atau faktor lain } \\
\text { menunjukkan adanya bias sebagai } \\
\text { faktor perancu dalam studi }\end{array}$ \\
\hline & & Kriteria Eksklusi \\
\hline 1 & & $\begin{array}{l}\text { Artikel dipublikasi bukan dalam } \\
\text { bahasa Inggris }\end{array}$ \\
\hline 2 & & $\begin{array}{l}\text { Artikel bukan merupakan original } \\
\text { study }\end{array}$ \\
\hline 3 & & $\begin{array}{l}\text { Artikel tidak relevan dengan Teknik } \\
\text { Delphi dan Farmasis, Praktik Farmasi } \\
\text { dan Pharmaceutical Care }\end{array}$ \\
\hline
\end{tabular}

Peran esensial farmasis pada pelayanan kesehatan adalah tema pertama yang diidentifikasi dalam tinjauan. Tema ini merupakan yang terbanyak dalam tinjauan yang terbagi lagi ke dalam beberapa subkategori yaitu peran esensial farmasis rumah sakit, peran esensial farmasis komunitas, peran esensial farmasis dari sisi regulasi. Misi profesi farmasi adalah meningkatkan kesehatan masyarakat dengan memastikan penggunaan obat yang aman, efektif, dan tepat. Praktik farmasi kontemporer mencerminkan paradigma yang berkembang dari paradigma di mana apoteker terutama mengawasi distribusi obat dan memberikan konseling pasien, hingga peran klinis yang lebih luas dan berbasis tim yang menyediakan manajemen terapi obat yang berpusat pada pasien, peningkatan kesehatan, dan layanan pencegahan penyakit (5). Penelitian terhadap peran esensial farmasis di rumah sakit menggunakan teknik Delphi dapat terbaca pada studi yang dilakukan oleh Carey et al. (2018); Dickman et al. (2017); Fernandez-Llamazares et al. (2013); Gyllensten et al. (2012); Holton et al. (2018); Krzyzaniak et al. (2017); Madaras-Kelly et al. (2014); Miller et al. (2012); Stewart et al. (2017), dan Weir et al. (2018). Penelitian Fernandez-Llamazares et al. (2013) dapat mewakili subtema peran farmasis di rumah sakit dimana mereka mendesain pembentukan konsensus model pelayanan kefarmasian anak dengan menggunakan teknik Delphi 2 putaran terhadap panelis yang merupakan farmasis klinis. Hasilnya adalah tercapainya konsensus $70 \%$ persetujuan oleh para panelis tentang desain model pelayanan kefarmasian anak (8). Sedangkan peran farmasis komunitas dapat terbaca pada penelitian Chisholm et al. (2018); Gibbins et al. (2017); dan Shawahna et al. (2016). Penelitian oleh Chisholm et al., 2016 berupa Delphi elektronik 3 putaran terhadap dokter, farmasis, dan peneliti kesehatan sosial untuk membuat konsensus rekomendasi untuk manajemen penyakit asma berdasarkan 5 klaster pasien di Asia, dapat mewakili subtema peran farmasis komunitas. Hasilnya adalah tercapainya konsensus yang sesuai dengan pendekatan manajemen yang 


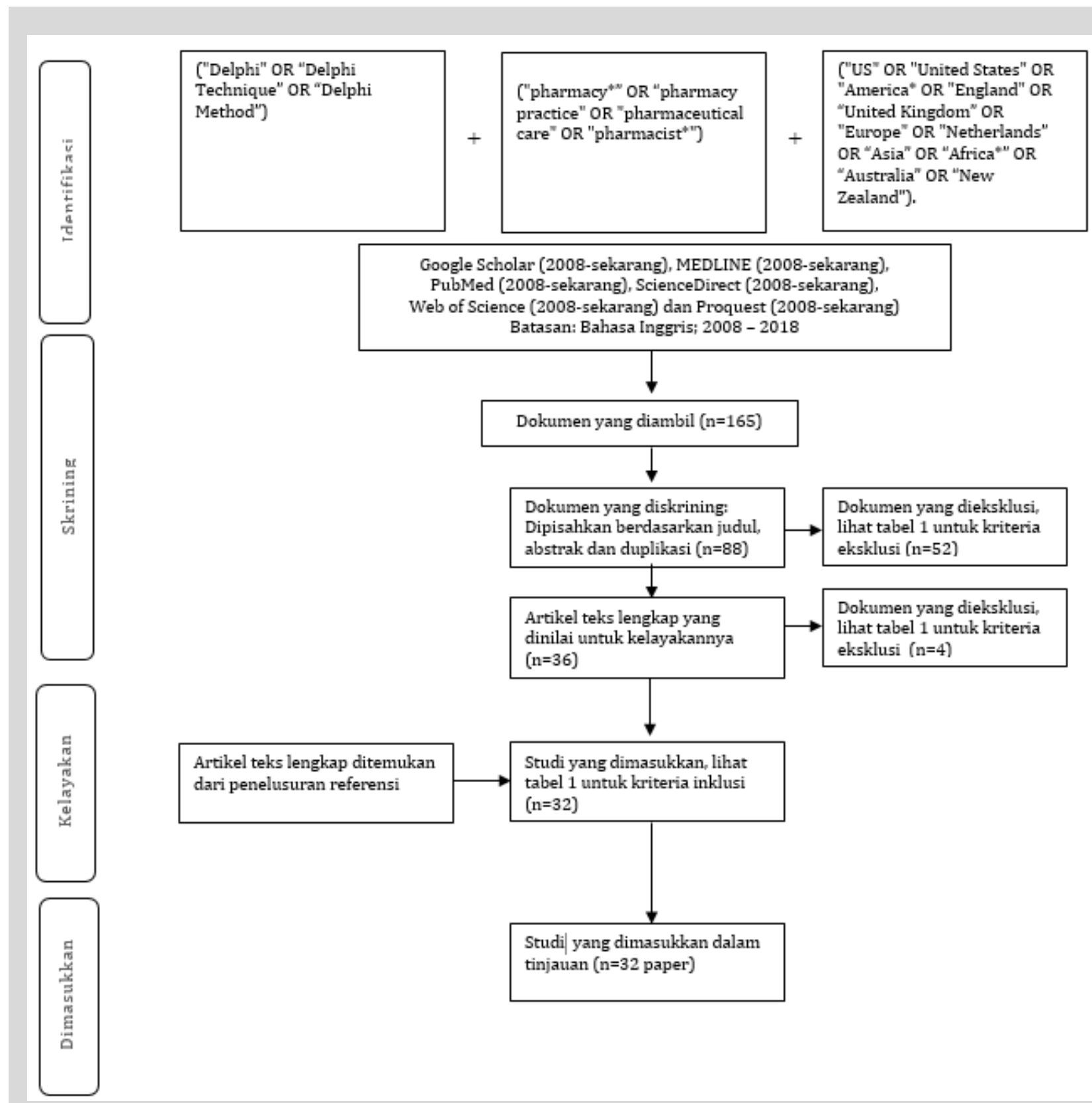

Gambar 1. Diagram proses seleksi studi menggunakan langkah flow chart disesuaikan dengan PRISMA statement

disesuaikan untuk semua klaster pasien asma di Asia (9). Sementara untuk peran esensial farmasis dari sisi regulasi dapat terlihat pada penelitian Ko et al. (2014) yang menyusun proses Delphi termodifikasi dan tinjauan literatur untuk mengeksplorasi isu dan hambatan terkait implementasi penerapan program vaksin dewasa berbasis farmasi dan mengembangkan rekomendasi pendukung program tersebut. Hasil penelitian ini menunjukkan bahwa pengusaha (employers) memainkan peranan penting dalam meminta perubahan desain program untuk mengusulkan vaksinasi berbasis farmasi. Penelitian ini juga menunjukkan kurangnya komunikasi yang konsisten antara farmasis dan penyedia layanan primer yang masih merupakan hambatan yang signifikan (10).

Profesionalisme farmasis adalah tema selanjutnya yang teridentifikasi dalan tinjauan. Hal ini terbagi dalam 3 subtema yaitu profesionalisme farmasis, profesionalisme teknisi farmasi, profesionalisme editor jurnal farmasi. Profesionalisme farmasis dapat terlihat pada penelitian Ignoffo et al. (2016); Janke et al. (2017); dan Miklich et al. (2016). Ignoffo et al., (2016) melibatkan panel ahli Delphi untuk mengidentifikasi estimasi berapa pelayanan klinis yang diberikan dan dikontribusikan oleh board-certified oncology pharmacists (BCOP) dalam setiap kunjungan pasien 30 menit di tahun 2020. Pada tahun 2020, diestimasikan 3.639 orang BCOP, sebanyak $62 \%$ akan menyelesaikan residensi farmasi onkologi terakreditasi, panelis Delphi sampai pada konsensus ( $80 \%$ persetujuan) bahwa ada 8 layanan perawatan pasien yang dapat BCOP berikan, dan dapat mengurangi potensi kunjungan pasien kanker hingga 50\% di tahun 2020.(11) Sedangkan profesionalisme teknisi farmasi terbaca pada hasil penelitian Koehler et al. (2017). Riset kualitatif multi metode untuk mengembangkan kerangka kompetensi untuk teknisi farmasi 2015-2017 menggunakan wawancara kelompok terfokus (focus group interview) terhadap teknisi farmasi dan farmasis dan stakeholder lainnya, selanjutnya analisis tema untuk kerangka awal menggunakan metode Delphi termodifikasi. Hasilnya adalah panel Delphi yang terdiri dari farmasis dan teknisi farmasi serta stakeholder lainnya berhasil membangun konsensus tentang kerangka kompetensi yang terdiri dari 6 domain (12). Ada hal yang menarik dari 
Tabel 2. Kriteria inklusi dan ekslusi penelitian

\begin{tabular}{|c|c|c|c|}
\hline $\begin{array}{c}\text { Peneliti, tahun } \\
\text { dan negara }\end{array}$ & Desain/ Populasi/ Setting & Luaran & Tema yang terbentuk \\
\hline $\begin{array}{l}\text { Aronson et al., } \\
\text { 2012(22), } \\
\text { Amerika Serikat }\end{array}$ & $\begin{array}{l}\text { Proses Delphi termodifikasi } 2 \text { putaran } \\
\text { menggunakan panelis } 34 \text { mahasiswa } \\
\text { farmasi. Untuk mengembangkan } \\
\text { keterlibatan profesional dan aktivitas } \\
\text { yang menghambatnya beserta } \\
\text { karakteristik aktivitasnya }\end{array}$ & $\begin{array}{l}\text {-Dihasilkan sebuah definisi } \\
\text { menggunakan } 3 \text { item yang mencapai } \\
\text { konsensus. } \\
\text {-Temuan dari studi memiliki implikasi } \\
\text { penciptaan pengalaman } \\
\text { pembelajaran yang melibatkan untuk } \\
\text { mahasiswa farmasi dan menyarankan } \\
\text { bahwa aktivitas tersebut } \\
\text { mengandung karakterisitik } \\
\text { profesional tertentu yang bisa jadi } \\
\text { lebih penting dari pada aktivitas } \\
\text { mereka }\end{array}$ & $\begin{array}{l}\text {-Pendidikan Farmasi } \\
\text {-Persepsi mahasiswa farmasi } \\
\text { terhadap keterlibatan profesional }\end{array}$ \\
\hline $\begin{array}{l}\text { Byrne et al., } \\
\text { 2010(23), Kanada }\end{array}$ & $\begin{array}{l}\text { Metode Delphi termodifikasi } 4 \text { putaran } \\
\text { untuk mencapai konsensus tentang } \\
\text { pernyataan untuk natural health } \\
\text { products (NHP) untuk mahasiswa } \\
\text { farmasi Kanada }\end{array}$ & $\begin{array}{l}\text { Tercapai konsensus terhadap } \\
\text { pernyataan kompetensi inti }\end{array}$ & $\begin{array}{l}\text {-Pendidikan Farmasi } \\
\text {-Kompetensi inti NHP untuk } \\
\text { mahasiswa farmasi Kanada }\end{array}$ \\
\hline $\begin{array}{l}\text { Bush et al., } \\
2017(24), \\
\text { Amerika Serikat }\end{array}$ & $\begin{array}{l}\text { Pendekatan Delphi } 3 \text { putaran } \\
\text { digunakan untuk mengidentifikasi dan } \\
\text { memprioritaskan nilai-nilai bersama } \\
\text { untuk organisasi mahasiswa yang } \\
\text { berafiliasi dengan sekolah farmasi, } \\
\text { melibatkan } 20 \text { orang presiden dan } \\
\text { wakil presiden organisasi mahasiswa }\end{array}$ & $\begin{array}{l}\text {-Sebanyak } 12 \text { nilai-nilai bersama } \\
\text { berhasil diidentifikasi dan diranking. } \\
\text {-Studi ini berkontribusi kecil pada } \\
\text { literatur tapi bertumbuh dalam hal } \\
\text { organisasi mahasiswa pada } \\
\text { pendidikan farmasi dan memberikan } \\
\text { dasar untuk studi selanjutnya }\end{array}$ & $\begin{array}{l}\text {-Pendidikan Farmasi } \\
\text {-Nilai-nilai bersama organisasi } \\
\text { mahasiswa farmasi untuk } \\
\text { pengembangan profesional dan } \\
\text { kepemimpinannya }\end{array}$ \\
\hline $\begin{array}{l}\text { Carey et al., } \\
2018(25), \\
\text { Australia }\end{array}$ & $\begin{array}{l}\text { Delphi termodifikasi digunakan untuk } \\
\text { mensurvei ahli (dokter, ahli gizi, } \\
\text { perawat dan farmasis) yang bekerja } \\
\text { untuk kasus intestinal failure (IF) tipe } \\
\text { III dan home parenteral nutrition (HPN) } \\
\text { dalam sistem pelayanan kesehatan } \\
\text { Australia }\end{array}$ & $\begin{array}{l}\text { Terbentuk konsensus lebih dari } 80 \% \\
\text { yang menyetujui bahwa tim ideal } \\
\text { harus terdiri dari dokter, perawat, ahli } \\
\text { gizi dan farmasi dan juga konsensus } \\
\text { tentang perlunya akses terhadap } \\
\text { dukungan psikologi }\end{array}$ & $\begin{array}{l}\text {-Peran Esensial Farmasis pada } \\
\text { Pelayanan Kesehatan } \\
\text {-Peran esensial farmasis RS dalam } \\
\text { tim IF HPN }\end{array}$ \\
\hline $\begin{array}{l}\text { Chisholm et al., } \\
\text { 2016(9), Inggris }\end{array}$ & $\begin{array}{l}\text { Delphi elektronik } 3 \text { putaran terhadap } \\
\text { dokter, farmasis, dan peneliti } \\
\text { kesehatan sosial untuk membuat } \\
\text { konsensus rekomendasi untuk } \\
\text { manajemen penyakit asma } \\
\text { berdasarkan } 5 \text { klaster pasien di Asia }\end{array}$ & $\begin{array}{l}\text { Tercapai konsensus yang sesuai untuk } \\
\text { pendekatan manajemen yang } \\
\text { disesuaikan untuk semua klaster } \\
\text { pasien asma di Asia }\end{array}$ & $\begin{array}{l}\text {-Peran Esensial Farmasis pada } \\
\text { Pelayanan Kesehatan } \\
\text {-Peran esensial farmasis komunitas } \\
\text { dalam konsensus rekomendasi } \\
\text { manajemen asma }\end{array}$ \\
\hline $\begin{array}{l}\text { Desnoyer et al., } \\
2017(15), \text { Swiss }\end{array}$ & $\begin{array}{l}5 \text { langkah studi yang meliputi } \\
\text { pemilihan domain obat, tinjauan } \\
\text { literatur, } 17 \text { wawancara } \\
\text { tersemistruktur, } 2 \text { putaran survei } \\
\text { Delphi proses translasi dan } \\
\text { pengembangan alat elektronik bagi } 40 \\
\text { orang dokter dan } 25 \text { farmasis klinis }\end{array}$ & $\begin{array}{l}\text { Dihasilkan } 160 \text { buah pernyataan } \\
\text { dengan } 17 \text { domain medis dan } 56 \\
\text { patologi untuk pasien penyakit dalam. }\end{array}$ & $\begin{array}{l}\text {-Protokol Manajemen Pengobatan } \\
\text {-Pengembangan daftar periksa } \\
\text { skrining resep internasional untuk } \\
\text { pasien penyakit dalam }\end{array}$ \\
\hline $\begin{array}{l}\text { Dickman et al., } \\
2017(26) \text {, Inggris }\end{array}$ & $\begin{array}{l}\text { Tinjauan terhadap praktik klinik terkini } \\
\text { dan identifikasi kombinasi obat yang } \\
\text { digunakan secara continuous } \\
\text { subcutaneous infusion (CSCI) oleh } \\
\text { farmasis profesional di Inggris }\end{array}$ & $\begin{array}{l}\text { Studi Delphi mengidentifikasi lima } \\
\text { kombinasi yang digunakan oleh } \\
\text { farmasis dalam CSCl }\end{array}$ & $\begin{array}{l}\text {-Peran Esensial Farmasis pada } \\
\text { Pelayanan Kesehatan } \\
\text {-Peran esensial farmasis RS dalam } \\
\mathrm{CSCl}\end{array}$ \\
\hline $\begin{array}{l}\text { Desselle et al., } \\
\text { 2016(27), } \\
\text { Amerika Serikat }\end{array}$ & $\begin{array}{l}\text { Prosedur Delphi } 4 \text { putaran yang } \\
\text { dimodifikasi dengan menggunakan } \\
\text { pertanyaan terbuka (Putaran 1) } \\
\text { dilakukan dengan } 13 \text { panelis dari } \\
\text { akademisi farmasi. Item yang } \\
\text { dihasilkan dievaluasi dan direvisi untuk } \\
\text { dimasukkan dalam putaran berikutnya. } \\
\text { Sebuah konsensus dicapai setelah } \\
\text { menyelesaikan empat putaran. }\end{array}$ & $\begin{array}{l}\text { Panel menghasilkan sebanyak } 26 \text { item } \\
\text { yang mengindikasikan perilaku peran } \\
\text { ekstra oleh kolega dosen yang } \\
\text { dianggap menyusun ukuran } \\
\text { kewarganegaraan, yang merupakan } \\
\text { manifestasi nyata dari kebersamaan. }\end{array}$ & $\begin{array}{l}\text {-Pendidikan Farmasi } \\
\text {-Identifikasi dan pengembangan } \\
\text { item yang terdiri dari perilaku } \\
\text { kewarganegaraan organisasi } \\
\text { diantara dosen farmasi }\end{array}$ \\
\hline $\begin{array}{l}\text { Fernandez- } \\
\text { Llamazares et al., } \\
\text { 2013(8), Spanyol }\end{array}$ & $\begin{array}{l}\text { Desain dan pembentukan konsensus } \\
\text { model pelayanan kefarmasian anak } \\
\text { dengan menggunakan teknik Delphi } 2 \\
\text { putaran terhadap panelis yang } \\
\text { merupakan farmasis klinis }\end{array}$ & $\begin{array}{l}\text { Tercapai konsensus } 70 \% \text { persetujuan } \\
\text { oleh para panelis tentang desain } \\
\text { model pelayanan kefarmasian anak }\end{array}$ & $\begin{array}{l}\text {-Peran Esensial Farmasis pada } \\
\text { Pelayanan Kesehatan } \\
\text {-Peran esensial farmasis klinis di RS } \\
\text { dalam desain model pelayanan } \\
\text { kefarmasian anak }\end{array}$ \\
\hline $\begin{array}{l}\text { Gibbins et al., } \\
2017(28) \\
\text { Australia }\end{array}$ & $\begin{array}{l}\text { Delphi termodifikasi } 3 \text { putaran untuk } \\
\text { membangun konsensus manajemen } \\
\text { penggunaan salah dan/ atau } \\
\text { ketergantungan obat analgesik } \\
\text { kombinasi non resep yang } \\
\text { mengandung kodein/ non-prescription } \\
\text { combination analgesics containing } \\
\text { codeine (NP-CACC) dari panelis yang } \\
\text { terdiri dari } 40 \text { orang farmasis }\end{array}$ & $\begin{array}{l}\text { Tercapai konsensus tingkat tinggi } \\
\text { yang menunjukkan bahwa strategi } \\
\text { yang dihasilkan merepresentasikan } \\
\text { pendekatan yang berguna dalam } \\
\text { manajemen penggunaan salah dan/ } \\
\text { atau ketergantungan obat NP-CACC }\end{array}$ & $\begin{array}{l}\text {-Peran Esensial Farmasis pada } \\
\text { Pelayanan Kesehatan } \\
\text {-Peran esensial farmasis komunitas } \\
\text { dalam menajemen obat NP-CACC }\end{array}$ \\
\hline
\end{tabular}


Tabel 2. Kriteria inklusi dan ekslusi penelitian (lanjutan)

\begin{tabular}{|c|c|c|c|}
\hline $\begin{array}{c}\text { Peneliti, tahun } \\
\text { dan negara }\end{array}$ & Desain/ Populasi/ Setting & Luaran & Tema yang terbentuk \\
\hline $\begin{array}{l}\text { Guerreiro et al., } \\
\text { 2018(16),Portugal }\end{array}$ & $\begin{array}{l}128 \text { item disusun dari analisis isi } \\
\text { kuesioner yang ada dan literatur, } \\
\text { menggunakan istilah yang lebih disukai } \\
\text { dari Klasifikasi Internasional WHO } \\
\text { untuk Keselamatan Pasien (versi } \\
\text { Portugal). Dua putaran e-Delphi } \\
\text { diselenggarakan, menggunakan panel } \\
\text { multidisiplin }\end{array}$ & $\begin{array}{l}\text {-Pada putaran pertama } 91 / 128 \\
(71,1 \%) \text { item mencapai tingkat } \\
\text { konsensus positif yang telah } \\
\text { ditentukan sebelumnya. } \\
\text {-Di babak kedua } 23 \text { item tambahan } \\
\text { mencapai konsensus positif, serta } \\
\text { tujuh item baru diturunkan oleh } \\
\text { panel. }\end{array}$ & $\begin{array}{l}\text {-Protokol Manajemen Pengobatan } \\
\text {-E-Delphi nasional untuk } \\
\text { pengukuran praktik pengobatan } \\
\text { yang aman di rumah sakit Portugal }\end{array}$ \\
\hline $\begin{array}{l}\text { Gyllensten et al., } \\
\text { 2012(29), Swedia }\end{array}$ & $\begin{array}{l}\text { Model konseptual drug-related } \\
\text { morbidity (DRM) berdasarkan pohon } \\
\text { keputusan. Panel ahli yang terdiri dari } \\
\text { farmasis menentukan kemungkinan } \\
\text { hasil terapi menggunakan proses } \\
\text { Delphi } 2 \text { putaran untuk } \\
\text { memperkirakan proporsi pasien } \\
\text { dengan DRM dan DRM yang dapat } \\
\text { dicegah serta cost-of-illness (COI) di } \\
\text { Swedia }\end{array}$ & $\begin{array}{l}\text { Menurut opini ahli farmasis, sejumlah } \\
\text { besar pasien di Swedia mengalami } \\
\text { DRM dan DRM yang dapat dicegah, } \\
\text { dan diperkirakan COI dari DRM sangat } \\
\text { luas }\end{array}$ & $\begin{array}{l}\text {-Peran Esensial Farmasis pada } \\
\text { Pelayanan Kesehatan } \\
\text {-Peran farmasis RS dalam } \\
\text { pembuatan pemodelan morbiditas } \\
\text { terkait obat }\end{array}$ \\
\hline $\begin{array}{l}\text { Helmy et al., } \\
\text { 2017(30), Swiss }\end{array}$ & $\begin{array}{l}\text { Studi ini menggunakan desain Delphi } \\
\text { reaktif di mana sekelompok panel ahli } \\
\text { diminta untuk menilai relevansi dan } \\
\text { kejelasan daftar item awal, selain } \\
\text { menyarankan item lebih lanjut dan / } \\
\text { atau modifikasi dari item awal }\end{array}$ & $\begin{array}{l}\text {-Daftar item awal dikembangkan dan } \\
\text { lingkungan survei online disiapkan } \\
\text { dan diuji oleh panitia pengarah. } \\
\text {-Berhasil diperoleh konsensus di } \\
\text { antara sekelompok panel ahli } \\
\text { mengenai daftar item yang akan } \\
\text { mendukung pengembangan EMERGE. }\end{array}$ & $\begin{array}{l}\text {-Protokol Pengobatan } \\
\text {-Protokol studi reaktif-Delphi } \\
\text { ESPACOMP Medication Adherence } \\
\text { Reporting Guidelines (EMERGE) }\end{array}$ \\
\hline $\begin{array}{l}\text { Holton et al., } \\
2018(31) \text {, Irlandia }\end{array}$ & $\begin{array}{l}\text { Delphi } 2 \text { putaran mengikuti tinjauan } \\
\text { sistematik terhadap kompendia obat } \\
\text { dan dokumen pedoman klinik } \\
\text { terhadap } 19 \text { orang profesional } \\
\text { kesehatan (dokter umum, dokter } \\
\text { geriatri, farmasis komunitas dan } \\
\text { farmasis rumah sakit, farmakologis } \\
\text { klinis dan farmasis) untuk membentuk } \\
\text { kriteria validasi konsensus interaksi } \\
\text { alkohol-obat yang berpotensi serius }\end{array}$ & $\begin{array}{l}\text {-Inventarisasi } 52 \text { interaksi alkohol- } \\
\text { obat yang berpotensi serius } \\
\text { dikembangkan oleh Kelompok } \\
\text { Pengarah Proyek. } \\
\text {-Dihasilkan kriteria validasi konsensus } \\
\text { POSAMINO (POtentially Serious } \\
\text { Alcohol-Medication Interaction in } \\
\text { Older Adults) }\end{array}$ & $\begin{array}{l}\text {-Peran Esensial Farmasis pada } \\
\text { Pelayanan Kesehatan } \\
\text {-Peran farmasis RS dalam } \\
\text { penyusunan kriteria validasi } \\
\text { konsensus interaksi alkohol-obat } \\
\text { yang berpotensi serius }\end{array}$ \\
\hline $\begin{array}{l}\text { Ignoffo et al., } \\
\text { 2016(11), } \\
\text { Amerika Serikat }\end{array}$ & $\begin{array}{l}\text { Proses panel ahli Delphi untuk } \\
\text { mengidentifikasi estimasi berapa } \\
\text { pelayanan klinis yang diberikan dan } \\
\text { dikontribusikan oleh board-certified } \\
\text { oncology pharmacists (BCOP) dalam } \\
\text { setiap kunjungan pasien } 30 \text { menit di } \\
\text { tahun } 2020\end{array}$ & $\begin{array}{l}\text {-Pada tahun 2020, diestimasikan } \\
3.639 \text { orang BCOP, sebanyak } 62 \% \\
\text { akan menyelesaikan residensi farmasi } \\
\text { onkologi terakreditasi, panelis Delphi } \\
\text { sampai pada konsensus ( } 80 \% \\
\text { persetujuan) bahwa ada } 8 \text { layanan } \\
\text { perawatan pasien yang dapat BCOP } \\
\text { berikan, dan dapat mengurangi } \\
\text { potensi kunjungan pasien kanker } \\
\text { hingga } 50 \% \text { di tahun } 2020\end{array}$ & $\begin{array}{l}\text {-Profesionalisme Farmasis } \\
\text {-Prediksi potensi kontribusi } \\
\text { farmasis dalam pengurangan } \\
\text { kunjungan pasien kanker }\end{array}$ \\
\hline $\begin{array}{l}\text { Janke et al., } \\
\text { 2017(13), } \\
\text { Amerika Serikat }\end{array}$ & $\begin{array}{l}\text { Metode Delphi termodifikasi } 3 \text { putaran } \\
\text { melibatkan } 19 \text { editor yang mewakili } 8 \\
\text { jurnal farmasi untuk mengidentifikasi } \\
\text { peer reviewer dan karakteristik peer } \\
\text { review yang meningkatkan kualitas } \\
\text { manuskrip dan keputusan editorial, } \\
\text { dan untuk mengidentifikasi elemen- } \\
\text { elemen berharga dari program } \\
\text { pelatihan peer reviewer }\end{array}$ & $\begin{array}{l}\text { Dihasilkan } 3 \text { karakteristik review yang } \\
\text { dinilai dibutuhkan atau sangat } \\
\text { membantu dalam meningkatkan } \\
\text { kualitas manuskrip: analisis kritis } \\
\text { manuskrip; umpan balik yang terdiri } \\
\text { dari kekuatan dan area untuk } \\
\text { perbaikan; dan berbicara tentang } \\
\text { kegunaan naskah dalam literatur }\end{array}$ & $\begin{array}{l}\text {-Profesionalisme Farmasis } \\
\text {-Persepsi editor jurnal farmasi } \\
\text { dalam meningkatkan kualitas } \\
\text { manuskrip dan keputusan editorial }\end{array}$ \\
\hline $\begin{array}{l}\text { Janke et al., } \\
\text { 2016(18), } \\
\text { Amerika Serikat }\end{array}$ & $\begin{array}{l}23 \text { orang ahli farmasi berpartisipasi } \\
\text { dalam proses Delphi yang dimodifikasi } \\
\text { untuk menggambarkan kompetensi } \\
\text { untuk memimpin penilaian, } \\
\text { didefinisikan sebagai individu yang } \\
\text { bertanggung jawab untuk penilaian } \\
\text { kurikuler dan penilaian yang } \\
\text { berhubungan dengan akreditasi } \\
\text { program doctor of pharmacy (PharmD) }\end{array}$ & $\begin{array}{l}\text {-12 kompetensi didefinisikan dan } \\
\text { dikelompokkan ke dalam } 3 \text { area: } \\
\text { konteks untuk penilaian, mengelola } \\
\text { proses penilaian, dan kepemimpinan } \\
\text { kegiatan penilaian. } \\
\text {-Untuk memverifikasi pekerjaan } \\
\text { panel, kompetensi penilaian dari } \\
\text { disiplin lain ditinjau dan } \\
\text { dibandingkan. }\end{array}$ & $\begin{array}{l}\text {-Pendidikan Farmasi } \\
\text {-Proses Delphi yang dimodifikasi } \\
\text { untuk menentukan kompetensi } \\
\text { untuk penilaian yang mendukung } \\
\text { program doktor farmasi }\end{array}$ \\
\hline $\begin{array}{l}\text { Kelly et al., } \\
\text { 2018(14), } \\
\text { Australia }\end{array}$ & $\begin{array}{l}5 \text { fase protokol studi termasuk survei } \\
\text { Delphi internasional termodifikasi } 3 \\
\text { putaran terhadap pasien dengan } \\
\text { berbagai kondisi rematik, pengasuh, } \\
\text { profesional kesehatan, peneliti dan } \\
\text { stakeholder lainnya untuk } \\
\text { mengembangkan rangkaian domain } \\
\text { inti pendahuluan kepatuhan } \\
\text { pengobatan dalam rematologi }\end{array}$ & $\begin{array}{l}\text { Diperoleh domain inti yang harus } \\
\text { terukur secara konsisten agar lebih } \\
\text { valid }\end{array}$ & $\begin{array}{l}\text {-Protokol pengobatan } \\
\text {-Domain inti kepatuhan } \\
\text { pengobatan }\end{array}$ \\
\hline
\end{tabular}


Tabel 2. Kriteria inklusi dan ekslusi penelitian (lanjutan)

\begin{tabular}{|c|c|c|c|}
\hline $\begin{array}{l}\text { Peneliti, tahun } \\
\text { dan negara }\end{array}$ & Desain/ Populasi/ Setting & Luaran & Tema yang terbentuk \\
\hline $\begin{array}{l}\text { Knapp et al., } \\
\text { 2014(19), } \\
\text { Amerika Serikat }\end{array}$ & $\begin{array}{l}\text { Proses Delphi untuk menentukan } \\
\text { apakah perundungan (bullying) } \\
\text { merupakan faktor signifikan dalam } \\
\text { training klinis farmasi }\end{array}$ & $\begin{array}{l}\text { Memberikan evidence (bukti) bahwa } \\
\text { perilaku perundungan terjadi dalam } \\
\text { pendidikan farmasi dan menunjukkan } \\
\text { perlunya perhatian terhadap masalah } \\
\text { ini karena dapat menyebabkan efek } \\
\text { merusak jangka panjang dan jangka } \\
\text { pendek }\end{array}$ & $\begin{array}{l}\text {-Pendidikan Farmasi } \\
\text {-Perundungan dalam training klinis } \\
\text { farmasi }\end{array}$ \\
\hline $\begin{array}{l}\text { Ko et al., } \\
\text { 2014(10), } \\
\text { Amerika Serikat }\end{array}$ & $\begin{array}{l}\text { Proses Delphi termodifikasi dan } \\
\text { tinjauan literatur untuk } \\
\text { mengeksplorasi isu dan hambatan } \\
\text { terkait implementasi penerapan } \\
\text { program vaksin dewasa berbasis } \\
\text { farmasi dan mengembangkan } \\
\text { rekomendasi pendukung program } \\
\text { tersebut }\end{array}$ & $\begin{array}{l}\text {-Hasil penelitian menunjukkan bahwa } \\
\text { employers (pengusaha) memainkan } \\
\text { peranan penting dalam meminta } \\
\text { perubahan desain program untuk } \\
\text { memasukkan vaksinasi berbasis } \\
\text { farmasi. } \\
\text {-Kurangnya komunikasi yang } \\
\text { konsisten antara farmasis dan } \\
\text { penyedia layanan primer masih } \\
\text { merupakan hambatan yang signifikan }\end{array}$ & $\begin{array}{l}\text {-Peran Esensial Farmasis pada } \\
\text { Pelayanan Kesehatan } \\
\text {-Peran farmasis dari sisi regulasi } \\
\text { dalam penerapan program vaksin } \\
\text { dewasa berbasis farmasi }\end{array}$ \\
\hline $\begin{array}{l}\text { Koehler et al., } \\
\text { 2018(12), } \\
\text { Belanda }\end{array}$ & $\begin{array}{l}\text { Riset kualitatif multi metode untuk } \\
\text { mengembangkan kerangka } \\
\text { kompetensi untuk teknisi farmasi } \\
\text { 2015-2017 menggunakan focus group } \\
\text { interview terhadap teknisi farmasi dan } \\
\text { farmasis dan stakeholder lainnya, } \\
\text { selanjutnya analisis tema untuk } \\
\text { kerangka awal menggunakan metode } \\
\text { Delphi termodifikasi }\end{array}$ & $\begin{array}{l}\text { Panel Delphi yang terdiri dari farmasis } \\
\text { dan teknisi farmasi serta stakeholder } \\
\text { lainnya berhasil membangun } \\
\text { konsensus tentang kerangka } \\
\text { kompetensi yang terdiri dari } 6 \text { domain }\end{array}$ & $\begin{array}{l}\text {-Profesionalisme Kefarmasian } \\
\text {-Profesionalisme Teknisi Farmasi } \\
\text {-Kerangka kompetensi teknisi } \\
\text { farmasi }\end{array}$ \\
\hline $\begin{array}{l}\text { Krzyzaniak et al., } \\
\text { 2017(32), } \\
\text { Australia dan } \\
\text { Polandia }\end{array}$ & $\begin{array}{l}16 \text { panelis berkontribusi sebagai panel } \\
\text { ahli dalam mengidentifikasi peran } \\
\text { esensial farmasis dan indikator kinerja } \\
\text { kunci farmasi yang relevan untuk } \\
\text { neonatal intensive units (NICU) di } \\
\text { Polandia menggunakan teknik Delphi }\end{array}$ & $\begin{array}{l}\text { Terdapat kebutuhan riset lanjutan } \\
\text { untuk menyusun standar praktik } \\
\text { minimum untuk farmasis Polandia } \\
\text { untuk meningkatkan kemajuan dan } \\
\text { standarisasi pelayanan farmasi rumah } \\
\text { sakit dalam memenuhi level praktik } \\
\text { NICU di dunia }\end{array}$ & $\begin{array}{l}\text {-Peran Esensial Farmasis pada } \\
\text { Pelayanan Kesehatan } \\
\text {-Peran esensial farmasis rumah } \\
\text { sakit (RS) di NICU }\end{array}$ \\
\hline $\begin{array}{l}\text { Madaras-Kelly et } \\
\text { al., 2014(33), } \\
\text { Amerika Serikat }\end{array}$ & $\begin{array}{l}\text { Metode Delphi termodifikasi berbasis } \\
\text { web terhadap } 24 \text { orang panelis yang } \\
\text { terdiri dari dokter dan farmasis untuk } \\
\text { mengembangkan skor numerik untuk } \\
\text { mengukur spektrum mikroba rejimen } \\
\text { antibiotik (nilai spektrum) dan metode } \\
\text { untuk mengindentifikasi kejadian de- } \\
\text { eskalasi antibiotik berdasarkan } \\
\text { penggunaan skor tersebut }\end{array}$ & $\begin{array}{l}\text { Para ahli mendukung konsep yang } \\
\text { digunakan dalam pengembangan } \\
\text { metrik. Sketsa yang ditampilkan } \\
\text { dalam Delphi menunjukkan } \\
\text { perubahan skor dengan tepat } \\
\text { mengklasifikasikan de-eskalasi } \\
\text { antibiotik kecuali yang melibatkan } \\
\text { penggantian antibiotik oral }\end{array}$ & $\begin{array}{l}\text {-Peran Esensial Farmasis pada } \\
\text { Pelayanan Kesehatan } \\
\text {-Peran farmasis RS dalam penilaian } \\
\text { spektrum antibiotik dan de- } \\
\text { eskalasinya }\end{array}$ \\
\hline $\begin{array}{l}\text { Mattingly et al., } \\
2017 \text { (17), } \\
\text { Amerika Serikat }\end{array}$ & $\begin{array}{l}32 \text { dekan sekolah farmasi negeri dan } \\
\text { swasta berpartisipasi dalam proses } \\
\text { Delphi } 3 \text { putaran untuk } \\
\text { mengidentifikasi kategori kualitas yang } \\
\text { digunakan untuk mengevaluasi } \\
\text { program PharmD institusi mereka }\end{array}$ & $\begin{array}{l}\text { Panelis bersepakat tentang } 9 \text { kategori } \\
\text { beserta metriknya untuk mengukur } \\
\text { kualitas dan membandingkan kualitas } \\
\text { antar program PharmD }\end{array}$ & $\begin{array}{l}\text {-Pendidikan Farmasi } \\
\text {-Kualitas dan metrik program } \\
\text { PharmD }\end{array}$ \\
\hline $\begin{array}{l}\text { Miklich et al., } \\
\text { 2016(34), } \\
\text { Amerika Serikat }\end{array}$ & $\begin{array}{l}15 \text { farmasis terlibat dalam teknik } \\
\text { konsensus Delphi online } 4 \text { putaran } \\
\text { untuk mendefinisikan keterlibatan } \\
\text { profesional dan menyusun daftar } \\
\text { belief (keyakinan) dan behaviors } \\
\text { characteristic (karakteristik perilaku) } \\
\text { farmasis yang terlibat secara } \\
\text { profesional }\end{array}$ & $\begin{array}{l}\text { Terbentuk pernyataan konsensus } \\
\text { tentang keyakinan dan karakteristik } \\
\text { perilaku farmasis yang terlibat secara } \\
\text { profesional serta konsensus tentang } \\
\text { definisi keterlibatan profesional }\end{array}$ & $\begin{array}{l}\text {-Profesionalisme Farmasis } \\
\text {-Kerangka Kompetensi Farmasis } \\
\text {-Keyakinan dan perilaku profesional } \\
\text { farmasis }\end{array}$ \\
\hline $\begin{array}{l}\text { Miller et al., } \\
\text { 2012(35), } \\
\text { Amerika Serikat }\end{array}$ & $\begin{array}{l}\text { Proses Delphi termodifikasi untuk } \\
\text { mengembangkan pernyataan } \\
\text { konsensus terkait multiple sclerosis } \\
\text { (MS) pada panelis yang terdiri dari ahli } \\
\text { dalam managed care (perawatan } \\
\text { terkelola) dan termasuk } 8 \text { direktur } \\
\text { farmasi dan } 6 \text { direktur medik }\end{array}$ & $\begin{array}{l}\text { Pernyataan konsensus dikembangkan } \\
\text { oleh panel perwakilan managed care } \\
\text { yang memberikan wawasan dalam } \\
\text { pengambilan keputusan dalam } \\
\text { formularium dan manajemen } \\
\text { penggunaan terapi MS }\end{array}$ & $\begin{array}{l}\text {-Peran Esensial Farmasis pada } \\
\text { Pelayanan Kesehatan } \\
\text {-Peran farmasis RS dalam } \\
\text { konsensus manajemen obat untuk } \\
\text { MS }\end{array}$ \\
\hline $\begin{array}{l}\text { Peirce et al., } \\
\text { 2012(20), } \\
\text { Amerika Serikat }\end{array}$ & $\begin{array}{l}\text { Delphi } 4 \text { putaran } 12 \text { panelis untuk } \\
\text { mengidentifikasi persepsi dosen } \\
\text { fakultas farmasi tentang pelanggaran } \\
\text { kontrak psikologis (Psychological } \\
\text { Contract Breaches)yang dapat } \\
\text { digunakan untuk memandu } \\
\text { peningkatan dalam perekrutan, } \\
\text { retensi, dan pengembangan fakultas. }\end{array}$ & $\begin{array}{l}\text { Daftar akhir dari pelanggaran kontrak } \\
\text { psikologis termasuk } 27 \text { item, setelah } \\
\text { modifikasi berdasarkan umpan balik } \\
\text { peserta dalam putaran berikutnya. }\end{array}$ & $\begin{array}{l}\text {-Pendidikan Farmasi } \\
\text {-Identifikasi pelanggaran kontrak } \\
\text { psikologis untuk memandu } \\
\text { perbaikan dalam perekrutan, } \\
\text { retensi, dan pengembangan staf } \\
\text { dosen farmasi }\end{array}$ \\
\hline
\end{tabular}


Tabel 2. Kriteria inklusi dan ekslusi penelitian (lanjutan)

\begin{tabular}{|c|c|c|c|}
\hline $\begin{array}{c}\text { Peneliti, tahun } \\
\text { dan negara }\end{array}$ & Desain/ Populasi/ Setting & Luaran & Tema yang terbentuk \\
\hline $\begin{array}{l}\text { Penm et al., } \\
\text { 2018(21), } \\
\text { Australia }\end{array}$ & $\begin{array}{l}24 \text { ahli dilibatkan dalam panel Delphi } \\
\text { untuk mengembangkan konsensus } \\
\text { definisi rekonsiliasi obat dan } \\
\text { menetapkan komponen esensial } \\
\text { rekonsiliasi obat berdasarkan } \\
\text { konsensus internasional }\end{array}$ & $\begin{array}{l}\text {-Panel ahli berhasil mencapai } \\
\text { konsensus tentang definisi tugas yang } \\
\text { terlibat dalam rekonsiliasi obat dan } \\
\text { konsep esensialnya setelah empat } \\
\text { putaran Delphi } \\
\text {-Definisi ini lebih luas cakupannya } \\
\text { dibanding definisi sebelumnya }\end{array}$ & $\begin{array}{l}\text {-Kebijakan Obat } \\
\text {-Konsep rekonsiliasi obat; } \\
\text { perspektif farmasi internasional }\end{array}$ \\
\hline $\begin{array}{l}\text { Shawahna et al., } \\
\text { 2016(36), } \\
\text { Palestina }\end{array}$ & $\begin{array}{l}\text { Studi deskriptif menggunakan teknik } \\
\text { Delphi yang melibatkan } 50 \text { orang } \\
\text { farmasis untuk mencapai konsensus } \\
\text { tentang definisi medication dispensing } \\
\text { errors pada praktik farmasi komunitas } \\
\text { Palestina }\end{array}$ & $\begin{array}{l}\text { Tercapai konsensus tentang definisi } \\
\text { MDE dan skenario yang mewakili } \\
\text { situasi MDE di praktik farmasi } \\
\text { komunitas Palestina }\end{array}$ & $\begin{array}{l}\text {-Peran Esensial Farmasis pada } \\
\text { Pelayanan Kesehatan } \\
\text {-Peran farmasis komunitas dalam } \\
\text { konsensus pencegahan MDE }\end{array}$ \\
\hline $\begin{array}{l}\text { Stewart et al., } \\
2017(37) \text {, Inggris }\end{array}$ & $\begin{array}{l}\text { Studi Delphi termodifikasi } 3 \text { putaran } 5 \\
\text { panelis yang terdiri dari pengambil } \\
\text { kebijakan, komisioner pelayanan } \\
\text { kesehatan, direktur pelayanan } \\
\text { kesehatan dan klinisi (dokter atau } \\
\text { farmasis) untuk menentukan tingkat } \\
\text { konsensus di seluruh Uni Eropa } \\
\text { terhadap struktur, proses dan luaran } \\
\text { yang diinginkan pada manajemen } \\
\text { polifarmasi pada pasien geriatri }\end{array}$ & $\begin{array}{l}\text { Tercapainya konsensus untuk } \\
\text { pernyataan terkait: potensi perolehan } \\
\text { dari manajemen polifarmasi; } \\
\text { pengembangan stratejik; pengukuran } \\
\text { indicator manajemen perubahan; } \\
\text { legislasi; peningkatan kesadaran, } \\
\text { tinjauan polifarmasi; dan visi Uni } \\
\text { Eropa }\end{array}$ & $\begin{array}{l}\text {-Peran Esensial Farmasis pada } \\
\text { Pelayanan Kesehatan } \\
\text {-Peran farmasis RS dalam } \\
\text { konsensus manajemen polifarmasi } \\
\text { pasien geriatri }\end{array}$ \\
\hline $\begin{array}{l}\text { Traynor et al., } \\
\text { 2013(38), } \\
\text { Amerika Serikat }\end{array}$ & $\begin{array}{l}26 \text { instruktur kepemimpinan } \\
\text { berpartisipasi dalam proses Delphi } \\
\text { termodifikasi } 3 \text { putaran untuk } \\
\text { mendefinisikan instruksi } \\
\text { kepemimpinan mahasiswa PharmD }\end{array}$ & $\begin{array}{l}12 \text { prinsip panduan yang terkait } \\
\text { konsep kepemimpinan dan filsafat } \\
\text { pendidikan didefinisikan dan dapat } \\
\text { dihubungkan terhadap } \\
\text { perkembangan pemikiran } \\
\text { kepemimpinan kontemporer }\end{array}$ & $\begin{array}{l}\text {-Pendidikan Farmasi } \\
\text {-Prinsip panduan untuk } \\
\text { pengembangan kepemimpinan } \\
\text { mahasiswa farmasi untuk } \\
\text { membantu tenaga administrasi dan } \\
\text { dosen untuk memperbaiki } \\
\text { kurikulum }\end{array}$ \\
\hline $\begin{array}{l}\text { Weir et al., } \\
2018(39) \text {, Irlandia } \\
\text { Utara }\end{array}$ & $\begin{array}{l}\text { Teknik Delphi } 2 \text { putaran yang } \\
\text { melibatkan } 17 \text { panelis yang terdiri dari } \\
\text { dokter, mikrobiologis klinis, farmasis, } \\
\text { perawat dan direktur layanan } \\
\text { perawatan di rumah untuk } \\
\text { memperoleh konsensus kriteria yang } \\
\text { diperlukan untuk tes tempat } \\
\text { perawatan yang dapat diterima untuk } \\
\text { deteksi infeksi saluran kemih }\end{array}$ & $\begin{array}{l}\text { Serangkaian kriteria yang disetujui } \\
\text { untuk tes tempat perawatan untuk } \\
\text { mendeteksi infeksi saluran kemih }\end{array}$ & $\begin{array}{l}\text {-Peran Esensial Farmasis pada } \\
\text { Pelayanan Kesehatan } \\
\text {-Peran esensial farmasis RS dalam } \\
\text { konsensus kriteria tes tempat } \\
\text { perawatan deteksi infeksi saluran } \\
\text { kemih }\end{array}$ \\
\hline
\end{tabular}

subtema profesionalisme farmasis ini dimana terdapat 1 subtema khusus tentang persepsi editor jurnal farmasi dalam meningkatkan kualitas manuskrip dan keputusan editorial. Hal ini dapat terlihat pada hasil penelitian Janke, et al. (2017). Metode Delphi termodifikasi 3 putaran melibatkan 19 editor yang mewakili 8 jurnal farmasi untuk mengidentifikasi peer reviewer dan karakteristik peer review yang meningkatkan kualitas manuskrip dan keputusan editorial, dan untuk mengidentifikasi elemen-elemen berharga dari program pelatihan peer reviewer. Dihasilkan 3 karakteristik review yang dinilai dibutuhkan atau sangat membantu dalam meningkatkan kualitas manuskrip: analisis kritis manuskrip; umpan balik yang terdiri dari kekuatan dan area untuk perbaikan; dan berbicara tentang kegunaan naskah dalam literature (13).

Protokol manajemen pengobatan adalah tema selanjutnya yang diidentifikasi dalam tinjauan ini. Tema ini memiliki subtema yaitu domain inti kepatuhan pasien, daftar periksa skrining resep, dan pengukuran praktik pengobatan aman. Kelly et al. (2018) meneliti pasien dengan berbagai kondisi rematik, terhadap panelis yang terdiri dari pengasuh, profesional kesehatan, peneliti dan stakeholder lainnya untuk mengembangkan rangkaian domain inti pendahuluan kepatuhan pengobatan dalam rematologi. Hasilnya adalah diperoleh domain inti yang harus terukur secara konsisten dalam intervensi rematologi validitas yang lebih baik (14). Desnoyer et al. (2017) menyusun 5 langkah studi yang meliputi pemilihan domain obat, tinjauan literatur, 17 wawancara tersemistruktur, 2 putaran survei Delphi proses translasi dan pengembangan alat elektronik bagi 40 orang dokter dan 25 farmasis klinis. Hasilnya adalah terbentuk 160 buah pernyataan daftar periksa skrining resep dengan 17 domain medis dan 56 patologi untuk pasien penyakit dalam (15). Guerreiro et al. (2018) berhasil menyusun protokol manajemen pengobatan dalam sebuah e-Delphi (electronic Delphi) nasional untuk pengukuran praktik pengobatan yang aman di rumah sakit Portugal (16).

\begin{tabular}{|c|c|}
\hline Tema & Subtema \\
\hline $\begin{array}{l}\text { Peran Esensial Farmasis } \\
\text { pada Pelayanan } \\
\text { Kesehatan }\end{array}$ & $\begin{array}{l}\text { Peran esensial farmasis RS, Peran } \\
\text { esensial farmasis komunitas, Peran } \\
\text { esensial farmasis dari regulasi }\end{array}$ \\
\hline $\begin{array}{l}\text { Profesionalisme } \\
\text { Kefarmasian }\end{array}$ & $\begin{array}{l}\text { Profesionalisme farmasis, } \\
\text { Profesionalisme teknisi farmasi, } \\
\text { Profesionalisme editor jurnal farmasi }\end{array}$ \\
\hline $\begin{array}{l}\text { Protokol Manajemen } \\
\text { Pengobatan }\end{array}$ & $\begin{array}{l}\text { Domain inti kepatuhan pasien, } \\
\text { Daftar periksa skrining resep, } \\
\text { Pengukuran praktik pengobatan } \\
\text { aman }\end{array}$ \\
\hline Pendidikan Farmasi & $\begin{array}{l}\text { Program pendidikan, Mahasiswa, } \\
\text { Dosen }\end{array}$ \\
\hline Kebijakan Obat & Konsep rekonsiliasi obat \\
\hline
\end{tabular}

Pendidikan Farmasi adalah tema terbanyak kedua yang teridentifkasi dalam tinjauan ini. Tema ini terdiri dari 3 
Tabel 3. Tema dan Subtema yang muncul dari artikel yang dimasukkan ke dalam studi

\begin{tabular}{|c|c|c|c|}
\hline Peringkat & Metrik & Peringkat rata-rata (SD) & $\mathbf{W}^{*}$ \\
\hline \multicolumn{4}{|c|}{ Operasional } \\
\hline 1 & Status akreditasi & $2.4(2.2)$ & .26 \\
\hline 2 & Dukungan terhadap mahasiswa & $2.7(1.5)$ & \\
\hline 3 & Rasio mahasiswa - dosen & $3.8(1.9)$ & \\
\hline 4 & Pendidikan interprofesional & $4.3(1.3)$ & \\
\hline 5 & Fasilitas & $4.4(1.7)$ & \\
\hline 6 & Penilaian rencana strategis & $5.0(2.1)$ & \\
\hline 7 & Program pascasarjana dan residensi & $5.4(1.5)$ & \\
\hline \multicolumn{4}{|c|}{ Penempatan } \\
\hline 1 & Penempatan kerja & $1.5(.9)$ & .58 \\
\hline 2 & Penempatan residensi (tingkat ketepatan) & $2.0(.6)$ & \\
\hline 3 & Penempatan pascasarjana & $2.8(.9)$ & \\
\hline 4 & Penempatan beasiswa & $3.7(.5)$ & \\
\hline \multicolumn{4}{|c|}{ Rekrutmen } \\
\hline 1 & $\begin{array}{l}\text { Data Kualitas Penerimaan (PCAT: Pharmacy } \\
\text { College Admission Test / IPK / Wawancara) }\end{array}$ & $1.7(.7)$ & .36 \\
\hline \multirow[t]{2}{*}{2} & Kredensial/ Kualifikasi dosen & $1.7(.7)$ & \\
\hline & $\begin{array}{lll}\text { Penerimaan } & \text { Situs } & \text { IPPE }\end{array}$ & & \\
\hline \multirow[t]{2}{*}{3} & $\begin{array}{l}\text { (Introductory Pharmacy Practice Experiences) / } \\
\text { APPE (Advanced Pharmacy Practice Experiences) } \\
\text { oleh Preceptor }\end{array}$ & $2.7(.6)$ & \\
\hline & \multicolumn{3}{|c|}{ Beasiswa } \\
\hline 1 & Publikasi/presentasi & $1.7(.7)$ & .28 \\
\hline 2 & Pendanaan & $2.3(1.2)$ & \\
\hline 3 & Riset mahasiswa pada pertemuan nasional & $2.6(1.0)$ & \\
\hline \multirow{2}{*}{4} & Kualitas Poster/ Capstone & $3.4(.9)$ & \\
\hline & \multicolumn{3}{|c|}{ Layanan } \\
\hline 1 & Komitmen fakultas kepada mahasiswa & $1.5(.6)$ & .36 \\
\hline 2 & Posisi Kepemimpinan dalam organisasi & $1.9(.8)$ & \\
\hline \multirow[t]{2}{*}{3} & Data Organisasi Profesional & $2.7(.6)$ & \\
\hline & Balik Stakeholder & & \\
\hline 1 & Umpan balik perusahaan & $3.0(1.8)$ & .17 \\
\hline 2 & $\begin{array}{l}\text { Evaluasi preseptor tentang mahasiswa } \\
\text { Survei AACP/ The American Association of Colleges }\end{array}$ & $3.1(1.7)$ & \\
\hline 3 & $\begin{array}{l}\text { of Pharmacy (alumni, preseptor, kurikulum, } \\
\text { dsb) }\end{array}$ & $3.3(2.2)$ & \\
\hline 4 & Peer review dari dosen & $4.1(2.1)$ & \\
\hline \multirow[t]{2}{*}{5} & Kelompok fokus mahasiswa & $4.4(1.7)$ & \\
\hline & Penilaian Keterampilan / Perilaku / Sikap (ACPE/ & & \\
\hline 6 & Accreditation Council for Pharmacy Education) & $4.9(1.8)$ & \\
\hline \multirow[t]{2}{*}{7} & Evaluasi mahasiswa oleh preseptor & $5.2(1.6)$ & \\
\hline & \multicolumn{3}{|c|}{ Pengujian } \\
\hline 1 & $\begin{array}{l}\text { NAPLEX (North American Pharmacist Licensure } \\
\text { Examination") }\end{array}$ & $1.0(.2)$ & .83 \\
\hline \multirow[t]{2}{*}{2} & $\begin{array}{l}\text { MPJE (Multistate Pharmacy Jurisprudence } \\
\text { Examination") }\end{array}$ & $2.0(.2)$ & \\
\hline & asilan Mahasiswa & & \\
\hline 1 & Kepuasan /Stres mahasiswa & $1.0(.2)$ & .83 \\
\hline 2 & Lainnya & $2.0(.2)$ & \\
\hline \multicolumn{4}{|c|}{ Kurikulum } \\
\hline 1 & Pembelajaran aktif & $2.0(1.1)$ & .07 \\
\hline 2 & Pembelajaran Berbasis Praktek & $2.6(.8)$ & \\
\hline 3 & Penilaian Kurikuler (CAPE, dll.) & $2.7(1.2)$ & \\
\hline 4 & Inovasi dalam Kurikulum & $2.7(1.2)$ & \\
\hline
\end{tabular}

subtema yaitu program pendidikan, mahasiswa, dan dosen. Terdapat 2 penelitian untuk subtema program pendidikan yaitu oleh Janke et al. (2016) dan Mattingly et al. (2017). Subtema program pendidikan dapat diwakili oleh penelitian Mattingly et al. (2017) dimana 32 dekan sekolah farmasi negeri dan swasta berpartisipasi dalam proses Delphi 3 putaran untuk mengidentifikasi kategori kualitas yang digunakan untuk mengevaluasi program PharmD (doctor of pharmacy) institusi mereka. Hasilnya panelis bersepakat tentang 9 kategori beserta metriknya untuk mengukur kualitas dan membandingkan kualitas antar program PharmD (untuk deskripsinya dapat dilihat pada tabel 4) (17) Janke et al. (2016) meneliti 23 orang ahli farmasi berpartisipasi dalam proses Delphi untuk menggambarkan kompetensi untuk memimpin penilaian, didefinisikan sebagai individu yang bertanggung jawab untuk penilaian kurikuler dan penilaian yang berhubungan dengan akreditasi program PharmD. Hasilnya adalah 12 kompetensi didefinisikan dan dikelompokkan ke dalam 3 area: konteks untuk penilaian, mengelola proses penilaian, dan kepemimpinan kegiatan penilaian. (18) Sedangkan untuk subtema mahasiswa terdapat dalam 4 penelitian yaitu Aronson et al. (2012); Byrne et al. (2010); Bush et al. (2010); dan Knapp et al. (2014). Salah satu studi yang menarik adalah penelitian yang dilakukan Knapp et al. (2014). Mereka menyusun proses Delphi untuk menentukan apakah perundungan (bullying) merupakan faktor signifikan dalam pelatihan klinis farmasi. Hasilnya adalah mereka berhasil memberikan bukti (evidence) bahwa perilaku perundungan terjadi dalam pendidikan farmasi dan menunjukkan perlunya 
perhatian terhadap masalah ini karena dapat menyebabkan efek merusak jangka panjang dan jangka pendek terhadap mahasiswa (19). Subtema dosen diwakili oleh penelitian Peirce et al. (2012) yang menyusun Delphi 4 putaran terhadap 12 panelis untuk mengidentifikasi persepsi dosen fakultas farmasi tentang pelanggaran kontrak psikologis (psychological contract breaches) yang dapat digunakan untuk memandu peningkatan dalam perekrutan, retensi, dan pengembangan fakultas. Hasilnya daftar akhir dari pelanggaran kontrak psikologis termasuk 27 item, setelah modifikasi berdasarkan umpan balik peserta dalam putaran berikutnya untuk memandu perbaikan dalam perekrutan, retensi, dan pengembangan staf dosen farmasi (20).

Kebijakan obat merupakan tema terakhir yang teridentifikasi dalam tinjauan. Berbeda dengan tema-tema sebelumnya, tema ini hanya terdiri dari 1 subtema yaitu konsep rekonsiliasi obat. Subtema ini ditunjukkan oleh penelitian Penm et al. (2018) dimana 24 ahli dilibatkan dalam panel Delphi untuk mengembangkan konsensus definisi rekonsiliasi obat dan menetapkan komponen esensial rekonsiliasi obat berdasarkan konsensus internasional. Hasil penelitiannya adalah panel ahli berhasil mencapai konsensus tentang definisi tugas yang terlibat dalam rekonsiliasi obat dan konsep esensialnya setelah empat putaran Delphi. Definisi ini lebih luas cakupannya dibanding definisi sebelumnya (21).

Peran penting farmasis dalam pelayanan kesehatan, profesionalisme farmasis, protokol manajemen pengobatan, pendidikan farmasi dan kebijakan obat adalah aspek-aspek utama terkait dengan isu kefarmasian kontemporer. Kelima tema ini merupakan bagian yang tidak terpisahkan dari kompetensi farmasis profesional yang mesti dikuasai oleh seorang lulusan pendidikan tinggi farmasi. Menurut Pauline dan Rouse (2010) ada tiga kompetensi dasar yang seharusnya termuat dalam kurikulum program profesi farmasi. Pertama, kemampuan lulusan untuk memberikan perawatan pasien bekerja sama dengan dokter dan anggota profesi kesehatan lain berdasarkan prinsip-prinsip terapetik dan data berbasis bukti, secara profesional, menggunakan teknologi dan mengembangkan pengetahuan biomedis, farmasetika, sosial/ behavioral/ administratif dan klinisnya yang dapat memberi dampak hasil terapi. Kedua, kemampuan untuk mengelola dan menggunakan sumber daya sistem pelayanan kesehatan bekerja sama dengan pasien, dokter dan profesional kesehatan lainnya untuk meningkatkan kesehatan; menyediakan, menilai dan mengkoordinasikan dengan aman, akurat, dan distribusi obat yang taat waktu; dan untuk memperbaiki hasil terapi penggunaan obat. Ketiga, mempromosikan peningkatan kesehatan, kesejahteraan, dan pencegahan penyakit bekerja sama dengan pasien, komunitas, populasi berisiko, dan anggota tim interprofesional penyedia layanan kesehatan lainnya (5). Mattingly et al. (2017) mendukung tesis ini berdasarkan hasil survei Delphi terhadap dekan-dekan sekolah farmasi di Amerika diperoleh konsensus bahwa kategori kualitas untuk pendidikan PharmD berturut-turut adalah kurikulum, penempatan alumni, umpan balik pemangku kepentingan, beasiswa, keberhasilan mahasiswa, pengujian, rekrutmen dan operasional sekolah farmasi (17). Dapat disimpulkan bahwa dari kelima tema dalam tinjauan ini, pendidikan farmasi merupakan kunci utama.

Berdasarkan pengetahuan penulis, studi systematic review ini adalah tinjauan komprehensif pertama tentang teknik Delphi terhadap studi terkait isu-isu kefarmasian terkini yang dipublikasikan dari tahun 2008 sampai 2018. Studi ini menggunakan pendekatan sistematik untuk mengurangi potensi bias dalam literatur yang ditinjau. Teknik Delphi merupakan metode pengambilan keputusan yang penting sehingga tinjauan ini menambah evaluasi penting riset ke dalam metodologi studi farmasi yang diteliti belakangan ini. Melalui tinjauan ini, diharapkan perhatian yang lebih terhadap beberapa aspek teknik Delphi yang dapat digunakan oleh pengambil kebijakan dan pembuat regulasi dalam bidang kefarmasian.

Meskipun tinjauan literatur ini mencakup rentangan yang luas dari teknik Delphi dalam kaitannya dengan isu-isu kefarmasian yang disusun melalui penelusuran yang berhatihati dari artikel original research, masih terdapat beberapa keterbatasan di dalamnya. Pertama, artikel yang ditinjau hanya yang diterbitkan dalam bahasa Inggris dan mengeksklusi artikel lainnya dalam bahasa yang lain sehingga dapat saja melewatkan informasi yang berharga dari negara-negara yang berbahasa di luar bahasa Inggris. Kedua, artikel yang diikutkan ke dalam studi adalah original study, mengeksklusi semua artikel selainnya termasuk review, editorial dan commentary. Hal ini dilakukan untuk menjamin bahwa semua temuan yang didiskusikan berasal dari data primer dan semuanya itulah yang telah dikumpulkan, namun dengan begitu dapat saja melewatkan informasi penting yang mendiskusikan teknik Delphi dan isu farmasi. Terlepas dari keterbatasan ini, tinjauan ini memberikan penilaian komprehensif atas teknik Delphi yang relevan yang digunakan untuk menjawab permasalahan di bidang kefarmasian. Penelitian selanjutnya terhadap topik ini sebaiknya mengeksplorasi lebih jauh penggunaan eDelphi dalam farmasi.

\section{KESIMPULAN}

Secara umum, melalui tinjauan ini dapat dibuktikan bahwa sejak awal kemapanannya, terdapat peningkatan penggunaan teknik Delphi untuk menyelesaikan masalahmasalah kefarmasian. Walaupun teknik ini berguna bagi profesi farmasis, penggunaannya di masa depan masih dapat dielaborasi lebih jauh untuk menghasilkan kebijakan dan konsensus dalam pemecahan masalah di bidang kefarmasian.

\section{UCAPAN TERIMA KASIH}

Terima kasih kepada Agathe Wehrli - Programme Coordinator FIP Pharmabridge; Reza Karimi - Dean School of Pharmacy Pacific University Oregon; dan Marina Suzuki Director for OGPER Pacific University Oregon. Ketiganya memungkinkan penulis untuk mendapatkan akses terhadap semua pangkalan data yang gunakan dalam studi ini.

\section{DAFTAR PUSTAKA}

1. Kennie-Kaulbach N, Farrell B, Ward N, Johnston S, Gubbels A, Eguale T, et al. Pharmacist provision of primary health care: A modified Delphi validation of pharmacists' competencies. BMC Fam Pract. 2012;13.

2. Cartwright AL, Spina SP. Author's Accepted Manuscript. Heal Policy Technol [Internet]. 2014; Available from: http://dx.doi.org/10.1016/j.hlpt.2014.01.003

3. Cantrill J A, Sibbald B, Buetow S. The Delphi and nominal group techniques in health services research. Int J Pharm Pract. 1996;4:67-74.

4. McMillan SS, King M, Tully MP. How to use the nominal group and Delphi techniques. Int J Clin Pharm. 2016;38(3):655-62.

5. Pauline N, Rouse MJ, Schlaifer M. Scope of contemporary pharmacy practice: Roles, responsibilities, and functions of pharmacists and pharmacy technicians. Consult Pharm [Internet]. 2010;25(6):382-94. Available from: http://dx.doi.org/10.1331/JAPhA.2010.10510

6. Poirier TI. A seminar course on contemporary pharmacy issues. Am J Pharm Educ. 2008;72(2):1-7.

7. Nosrgaard LS, Morgall JM, Bissell P. Arguments for theory-based Pharmacy Practice research. Int J Pharm Pract [Internet]. 2000;8(2):7781. Available from: http://doi.wiley.com/10.1111/j.20427174.2000.tb00989.x

8. Fernández-llamazares CM, Hernández-gago Y, Pozas M, Villaronga M, Álvarez-del-vayo C, Caba MJ, et al. Two-round Delphi technique for the consensual design of a paediatric pharmaceutical care model. 2013;68:31-7.

9. Chisholm A, Price DB, Pinnock H, Lee TT, Roa C, Cho SH, et al. Personalising care of adults with asthma from Asia: A modified e-Dephi consensus study to inform management tailored to attitude and control profiles. npj Prim Care Respir Med. 2017;27(August):1-10. 
10. Ko KJ, Wade RL, Yu H-T, Miller RM, Sherman B, Goad J. Implementation of a Pharmacy-Based Adult Vaccine Benefit: Recommendations for Commercial Health Plan Benefit. J Manag Care Pharm [Internet] 2014;20(3):273-82. Available from http://www.jmcp.org/doi/10.18553/jmcp.2014.20.3.273

11. Ignoffo R, Knapp K, Barnett M, Barbour SY, D'Amato S, Iacovelli L, et al Board-Certified Oncology Pharmacists: Their Potential Contribution to Reducing a Shortfall in Oncology Patient Visits. J Oncol Pract [Internet] 2016;12(4):e359-68. Available http://ascopubs.org/doi/10.1200/JOP.2015.008490

12. Koehler TC, Bok H, Westerman M, Jaarsma D. Developing a competency framework for pharmacy technicians: Perspectives from the field. Res Soc Adm Pharm [Internet]. 2018; Available from: https://doi.org/10.1016/j.sapharm.2018.06.017

13. Janke KK, Bzowyckyj AS, Traynor AP. Editors' perspectives on enhancing manuscript quality and editorial decisions through peer review and reviewer development. Am J Pharm Educ. 2017;81(4).

14. Kelly A, Tong A, Tymms K, March L, Craig JC, De Vera M, et al. Outcome Measures in Rheumatology - Interventions for medication Adherence (OMERACT-Adherence) Core Domain Set for Trials of Interventions for Medication Adherence in Rheumatology: 5 Phase Study Protocol. Trials. 2018;19(1):1-13.

15. Desnoyer A, Blanc AL, Pourcher V, Besson M, Fonzo-Christe C, Desmeules J, et al. PIM-Check: Development of an international prescriptionscreening checklist designed by a Delphi method for internal medicine patients. BMJ Open. 2017;7(7):1-20.

16. Guerreiro MP, Plácido M, Barros CT, Coelho A, Graça A, Gaspar MJ, et al. A national e-Delphi towards the measurement of safe medication practices in Portuguese hospitals. Eur J Hosp Pharm. 2018;25(2):103-6.

17. Mattingly TJ, Romanelli F, Cain J, Schlesselman LS. Measuring up Defining the quality of PharmD programs. Am J Pharm Educ. 2017;81(9):47-52.

18. Janke KK, Kelley KA, Sweet B V., Kuba SE. A modified Delphi process to define competencies for assessment leads supporting a doctor of pharmacy program. Am J Pharm Educ. 2016;80(10).

19. Knapp K, Shane P, Sasaki-Hill D, Yoshizuka K, Chan P, Vo T. Bullying in the clinical training of pharmacy students. Am J Pharm Educ. 2014;78(6):117.

20. Peirce GL, Desselle SP, Draugalis JR, Spies AR, Davis TS, Bolino M. Identifying psychological contract breaches to guide improvements in faculty recruitment, retention, and development. Am J Pharm Educ [Internet]. 2012;76(6). Available from: http://www.scopus.com/inward/record.url?eid=2-s2.0 84865190359\&partnerID=tZOtx3y1

21. Penm J, Vaillancourt R, Pouliot A. Defining and identifying concepts of medication reconciliation: An international pharmacy perspective. Res Soc Adm Pharm. 2018; (xxxx).

22. Aronson BD, Janke KK, Traynor AP. Investigating student pharmacis perceptions of professional engagement using a modified Delphi process. Am J Pharm Educ. 2012;76(7).

23. Byrne A, Boon H, Austin Z, Jurgens T, Raman-Wilms L. Core competencies in natural health products for Canadian pharmacy students. Am J Pharm Educ [Internet]. 2010;74(3):45. Available from: http://www.embase.com/search/results?subaction=viewrecord\&from =export\&id=L360292957\%0Ahttps://resolver.library.uq.edu.au/?sid= EMBASE\&issn=15536467\&id=doi:\&atitle=Core+competencies + in + natu ral+health+products+for+Canadian+pharmacy+students.\&stitle $=\mathrm{Am}+\mathrm{J}+$ Phar

24. Bush AA, Buhlinger KM, McLaughlin JE. Identifying shared values for school-affiliated student organizations. Am J Pharm Educ. 2017;81(9):53-9.
25. Carey S, Kalachov M, Jones L, Koh C. Development of consensus on models of care in adults with intestinal failure using a modified Delphi approach. J Gastroenterol Hepatol. 2018;33(9):1598-602.

26. Dickman A, Bickerstaff M, Jackson R, Schneider J, Mason S, Ellershaw J. Identification of drug combinations administered by continuous subcutaneous infusion that require analysis for compatibility and stability. BMC Palliat Care. 2017;16(1):22.

27. Desselle SP, Semsick GR. Identification and development of items comprising organizational citizenship behaviors among pharmacy faculty. Am J Pharm Educ. 2016;80(10).

28. Gibbins AK, Wood PJ, Spark MJ. Managing inappropriate use of nonprescription combination analgesics containing codeine: A modified Delphi study. Res Soc Adm Pharm [Internet]. 2017;13(2):369-77. Available from: http://dx.doi.org/10.1016/j.sapharm.2016.02.015

29. Gyllensten H, Hakkarainen KM, Jönsson AK, Sundell KA, Hägg S, Rehnberg $\mathrm{C}$, et al. Modelling drug-related morbidity in Sweden using an expert panel of pharmacists'. Int J Clin Pharm. 2012;34(4):538-46.

30. Helmy R, Zullig LL, Dunbar-Jacob J, Hughes DA, Vrijens B, Wilson IB, et al. ESPACOMP Medication Adherence Reporting Guidelines (EMERGE): A reactive-Delphi study protocol. BMJ Open. 2017;7(2):1-7.

31. Holton AE, Gallagher PJ, Ryan C, Fahey T, Cousins G. Consensus validation of the POSAMINO (POtentially Serious Alcohol-Medication INteractions in Older adults) criteria. BMJ Open. 2017;7(11):1-9.

32. Krzyżaniak N, Pawłowska I, Bajorek B. Quality pharmacy services and key performance indicators in Polish NICUs: a Delphi approach. Int J Clin Pharm [Internet] 2018;40(3):533-42. Available from: https://doi.org/10.1007/s11096-018-0623-y

33. Madaras-Kelly K, Jones M, Remington R, Hill N, Huttner B, Samore M Development of an Antibiotic Spectrum Score Based on Veterans Affairs Culture and Susceptibility Data for the Purpose of Measuring Antibiotic De-Escalation: A Modified Delphi Approach. Infect Control Hosp Epidemiol [Internet]. 2014;35(09):1103-13. Available from: https://www.cambridge.org/core/product/identifier/S0899823X0019 2815/type/journal_article

34. Miklich MA, Reed BN, Mattingly TJ, Haines ST. Beliefs and behaviors of professionally engaged pharmacists. J Am Pharm Assoc [Internet]. 2016;56(4):405-11. Available from: http://dx.doi.org/10.1016/j.japh.2016.03.011

35. Miller RM, Happe LE, Meyer KL, Spear RJ. Approaches to the Management of Agents Used for the Treatment of Multiple Sclerosis: Consensus Statements from a Panel of U.S. Managed Care Pharmacists and Physicians. J Manag Care Pharm [Internet]. 2012;18(1):54-62. Available from: http://www.jmcp.org/doi/10.18553/jmcp.2012.18.1.54

36. Shawahna R, Haddad A, Khawaja B, Raie R, Zaneen S, Edais T. Medication dispensing errors in Palestinian community pharmacy practice: a formal consensus using the Delphi technique. Int J Clin Pharm. 2016;38(5):1112-23.

37. Stewart D, Gibson-Smith K, MacLure K, Mair A, Alonso A, Codina C, et al. A modified Delphi study to determine the level of consensus across the European Union on the structures, processes and desired outcomes of the management of polypharmacy in older people. PLoS One. 2017;12(11):1-17.

38. Traynor AP, Boyle CJ, Janke KK. Guiding principles for student leadership development in the doctor of pharmacy program to assist administrators and faculty members in implementing or refining curricula. Am J Pharm Educ. 2013;77(10).

39. Weir NJM, Pattison SH, Kearney P, Stafford B, Gormley GJ, Crockard MA, et al. Criteria required for an acceptable point-of-care test for UTI detection: Obtaining consensus using the Delphi technique. PLoS One. 2018;13(6):1-13. 